\title{
The role of public spaces in creating place attachment (example of Zacisze, Warsaw housing estate)
}

\begin{abstract}
This article raises the question of place attachment in the context of an increasingly important factor, that is the use of gathering and leisure places. The author publishes findings of a survey conducted among the residents of Zacisze, Warsaw, a detached housing estate with a very poor range of public places for gathering and leisure. The study has proved that the use of local public spaces, as a specific category of place, reinforces attachment to the whole housing estate. The study also confirms the important role that social factors have in building place attachment. Conditions already exist for considering social factors more important than physical ones in building a positive relationship with a territory.
\end{abstract}

Keywords

Place attachment $\cdot$ public space $\cdot$ social factor $•$ Zacisze $\cdot$ Warsaw

(c) University of Warsaw - Faculty of Geography and Regional Studies

\author{
Dorota Mantey
}

Department of Urban Geography and Spatial Management, Faculty of Geography and Regional Studies,

University of Warsaw, Poland

e-mail:d.mantey@uw.edu.pl

Received: 16 December 2014

Accepted: 8 July 2015
Introduction

Context and the aim of the research

The problem of attachment to a place of residence is the subject of interest for several scientific disciplines: geography, sociology, and environmental psychology. Along with intensive and ongoing revitalization processes (also in Poland), cities have gained a new factor that positively influences the relationship to territory, namely the possibility of using attractive, pro-social public spaces. This article is a contribution to the debate on the role of space, as understood according to the classical definition determined by Tuan $(1975,1977)$, in an era of globalization, virtualization and the hectic pace of everyday life. Some authors claim that in recent years, contrary to popular belief, the importance of specific places has increased (Gustafson 2006; Janz 2005; Kruger \& Jakes 2003; after: Lewicka 2011). Within a mosaic of factors affecting relationship to territory, it is interesting what role is played by available and accessible public spaces on the one hand; and the social context, understood as a relationship to other residents; on the other

The purpose of this article is to determine the importance of public spaces in building positive relationships with a housing estate. The results will be related to social relationships, another important factor that plays a role in strengthening place attachment. This article proposes an approach to the problem of the relationship to a particular territory based on the land use issue, including the presence of certain types of space within the territory's borders, while environmental psychology focuses more on the environment and its characteristics as a factor in determining the identity of the individual (Lewicka 2011; Bonaiuto et al. 2003; Fornara et al. 2009). The author focuses on the role of a specific category of places in building identification with the larger section of the city; in this case with a housing estate in its administrative meaning, and ignores the importance of individual places for building the identity of the individual.

Study area and methodology

Zacisze, one of Warsaw's housing estates, has been intentionally selected as a study area. It is a part of the city that has a limited number of public spaces, but is highly attractive because of its built environment (predominately detached houses) and its suburban character. Unfortunately, its location in Warsaw's north Praga (Targówek district) decreases somewhat the prestige of the housing estate: Targowek, in terms of district attachment, scores an average result compared with other districts ${ }^{1}$.

Research on the attachment to a district (which can also include the larger housing estates that function as administrative units of the city) are rare (Lewicka 2010), perhaps due to the heterogeneity of the districts of large cities, either in terms of physical, cultural, or social dimension. The homogeneous Zacisze is; therefore, closer to the category of neighbourhood than district, but on the other hand, it has clearly defined boundaries and operates on the map of Warsaw as a separate administrative unit with a rank lower than that of district.

${ }^{1}$ Detailed results from the research on the attachment to the district and the neighborhood (understood individually by each respondent) can be found on the website of the City of Warsaw (http://www.um.warszawa.pl/jakosc-zycia-2014/). Some of them will be cited later in this article. 
The author of the article, by selecting the area of research, has assumed that if the relationship between the use of places where people meet and spend their free time, and the attachment to the housing estate with limited access to such spaces, is proved; then the argument for the above-mentioned dependence will be strengthened.

The aim of this paper has been achieved by the use of a survey carried out among residents of Zacisze in March and April 2014. Half of the respondents were selected on the basis of counting off every third house (the interviewer asked the household member who had celebrated one's birthday last, to participate in the study). The other half was selected from among passers-by on the streets. As a result a total number of 149 questionnaires were collected.

Among all people surveyed, $56.4 \%$ were women and $43.6 \%$ were men. The age structure of the respondents is shown in Table 1., and the length of residency in Zacisze in Table 2.

It was noted that $56.4 \%$ of respondents declared that for most of the day they stayed in Zacisze, while $43.6 \%$ spent more of their daily time outside it.

Place attachment - theoretical context and the state of knowledge

Place attachment is mainly an area of interest for psychology, in particular environmental psychology, which combines the experience and knowledge of indigenous science and related disciplines such as sociology, geography, architecture, and urban planning (Lewicka 2004). The variety of dimensions of man's relationship with the environment is manifested in a multiplicity of concepts. The most commonly used term in the literature, which on the one hand defines these relationships, and on the other permits their measurement, is place attachment. According to the proposal by Hidalgo and Hernández (2001), place attachment is a positive emotional bond between the individual and a given space. The main feature of this relationship is the tendency to maintain a closeness with that space, i.e. relationship of familiarity. The result is a greater interest in the place, the desire to decide on its future, as well as to take care of its condition (Pawłowska 1996 after: Rykiel 1999). In the case of attachment the emphasis is therefore on the affective aspect.

Attachment to place can be considered using two dimensions: the functional (or practical), and the emotional. Stronger ties bind us to the environment if it meets our needs, both physically and psychologically, and is consistent with our goals and lifestyle. Emotional attachment, in turn, is related to auto-identification. The easier it is to recognise the space, and the more positive an effect it has on the self-esteem of the person, the stronger the emotional attachment is (Livingston et al. 2008).

Place attachment is often equated with place identity. This, while it seems to refer to the same dimension of human relationships with the environment, gives priority to the cognitive component. It permits the building of separate self-images and place images that are distinct from those of other people, communities and regions (Knez 2005, after: Rychlewska 2010). As Droseltis and Vignoles (2010) suggest, place identity can be considered, among other dimensions, within the dimension of place attachment (the stronger the attachment, the stronger the identity and vice versa; although it is worth noting that the relationships between these two elements of one's identity have not been fully investigated, and there is no certainty as to if mutual influence, if any, exists).

The space that is nearest due to the daily interactions that occur in it, is seen as the natural pattern of normality, and gives a sense of security (Burdzik 2012), which is a basic human need. It has been proved that the strongest emotional relationship with an environment occurs in the case of small communities and increases with the length of time lived in a particular territory
Table 1. Age of respondents

\begin{tabular}{|c|c|c|c|c|}
\hline $\begin{array}{c}\mathbf{1 8 - 2 5} \\
\text { years old }\end{array}$ & $\begin{array}{c}\mathbf{2 6 - 3 5} \\
\text { years old }\end{array}$ & $\begin{array}{c}\mathbf{3 6 - 4 5} \\
\text { years old }\end{array}$ & $\begin{array}{c}\mathbf{4 6 - 6 0} \\
\text { years old }\end{array}$ & $\begin{array}{c}\mathbf{6 1} \text { years } \\
\text { old or } \\
\text { more }\end{array}$ \\
\hline $23.5 \%$ & $21.5 \%$ & $13.4 \%$ & $20.1 \%$ & $21.5 \%$ \\
\hline
\end{tabular}

Source: own data

Table 2. Length of time residing in Zacisze

\begin{tabular}{|c|c|c|c|}
\hline $\begin{array}{c}\text { no more than } \\
\text { 2 years }\end{array}$ & $\mathbf{3 - 1 0}$ years & $\begin{array}{c}\mathbf{1 1 - 2 0} \\
\text { years }\end{array}$ & $\begin{array}{c}\mathbf{2 1} \text { years } \\
\text { or longer }\end{array}$ \\
\hline $12.8 \%$ & $24.2 \%$ & $30.2 \%$ & $32.9 \%$ \\
\hline
\end{tabular}

Source: own data

(Lewicka 2006, 2008; Lewicka et al. 2007; Michalska 2003). For place attachment, spatial mobility also remains significant. If we assume that the level of territorial awareness is a function of the amount of time spent in a given territory, the increased spatial mobility of the inhabitants of a city implies a weakening of local territorial awareness (Rykiel 1999). Users of the space feel they own it when they can customize it to suit their individual needs and consequently use it regularly (Hester 1984). Livingston et al (2008), in reviewing the research on place attachment, also pay attention to other important factors favouring a stronger place identity, such as owning a house/apartment or higher education. Another important factor is social context: it is more likely that a person will be more strongly attached to an area in which one has many friends and acquaintances, in which involvement in local organizations is greater, and to which other people also feel attached. It can therefore be concluded that place attachment is mostly a product of relationships with other residents (social factor). An example of casual and informal groups, the existence of which translates into a stronger identification with the territory, are parents who talk to each other while their children play, dog owners who meet in the same park, people who come together to play basketball, or participants in neighbourhood picnics (Carr et al. 1992). It's worth noting; however, that these activities require the existence of public spaces that are accessible to all, friendly, safe, and conducive to establishing interpersonal relations.

A review of the research on the issue of place attachment made by Lewicka (2011) shows that in heterogeneous communities (eg. in terms of ethnicity), ties with the territory are weaker; although Stolle et al. (2008) have shown that good relations between neighbours and frequent conversations (social factor) can improve the relationship with the territory and significantly weaken the identified negative dependency.

The relationship to territory can be seen in the context of the social and physical factors that frequently occur together. Some feel attached to a place because of the strong ties with other residents, family roots or religious symbolism. Attachment for others is based on the physical resources of the area, such as natural assets, opportunities for recreation and leisure, or a generally stimulating environment (Lewicka 2011). Although the catalogue of elements reinforcing place attachment is very wide, we still do not know all the factors that shape the relationship with territory. What is interesting is that studies have shown that physical factors are better predictors of attachment to the smallest scale of place (apartment, building), and social factors 
more accurately predict attachment to the larger parts of the urban fabric (neighbourhood, district) (Lewicka 2010).

According to E. Talen (1999), who promotes the principles of New Urbanism, community relationships are enhanced by the following dimensions of the physical environment:

1. Architecture and site design;

2. Density and scale (preferably a small scale neighbourhood/ settlement with well-defined boundaries, a clear centre and a legible grid of streets);

3. Public spaces (places where people can gather);

4. Mixed land use (places of residence juxtaposed with places to work, shop or participate in recreation, create a multipurpose space, which, according to J. Jacobs (1961), increases the opportunities of chance encounters that strengthen interpersonal relationships).

The most important factors in the process of building positive relationships with the territory is the existence, within its borders, of a cultural area bringing together material, aesthetic and symbolic values (Wallis 1979). According to A. Górka (2013); however, the specificity of such an area is not so much a result of the objective advantages of the space itself, but is a consequence of a social group operating in such an area and identifying with it. Apart from cultural areas there are also other types of public spaces, with a slightly lower rank, but also attractive. The research done by Rogers and Sukolratanametee (2009) has proved that a positive impact on community building, and thus the identification with a given space, provides an attractive environment, in particular ecological spaces, such as mini-parks and pedestrian areas, because they encourage the spending of time outdoors, establishing relationships with other people and undertaking various kinds of activity.

The above considerations can be summarized as follows: the existence of an area used jointly by its inhabitants has a significant effect on place attachment, not so much because of the physical attractiveness of the territory, but due to its prosocial character. It also happens that place attachment is built regardless of the physical characteristics of the space and the way it is developed. On the other hand, there are many studies on the evaluation of cities and their parts through the prism of the presence of factors which enhance the quality of urban space in its physical dimension (Nasar 1998; Jacobs 1999; Carr et al. 1992; Gehl 2010). According to Lewicka (2010); however, there are still no studies that confirm the role of elements that determine "great" public spaces, as predictors of emotional bonds with the territory. Analysing elements that determine the quality of public spaces is possible only when residents have the opportunity to use them. The very presence of public space is therefore a necessary condition in the case of such analysis.

\section{Zacisze - a housing estate deprived of public spaces}

Zacisze is a housing estate in the north-east of Warsaw, with a population of approximately 14 thousand people. It is dominated by densely built-up, detached houses, although for the last several years the number of multi-family buildings on the outskirts of the housing estate has increased. Its specificity consists of a suburban character and its proximity to the centre.

The history of Zacisze dates back to the nineteenth century, when it served as a summer housing estate for the wealthy inhabitants of Warsaw. In 1895 Zacisze had a population of 100 people, and by 1939 it had reached 2000. In 1951 Zacisze was incorporated into Warsaw. That moment was the beginning of a massive inflow of new settlers and the intensive development of the housing estate.

While developing Zacisze, provision for public space and gathering places for residents was unfortunately neglected (even a park that existed there several years ago has been built over). At the time of the survey, inhabitants of Zacisze only had the use of one small local square located on the periphery of the housing estate ${ }^{2}$. It's worth noting that the square was opened relatively recently, in October 2013. Another feature worth mentioning is a narrow water channel that flows through the whole housing estate. Despite its large recreational potential, not all of its length is available for residents. In considering sports and recreational areas, residents can only enjoy one sports ground, which is located in the centre of the housing estate near the House of Culture "Zacisze", an important place on the artistic activity map of Targówek (the Warsaw district to which Zacisze belongs). Children and youth also meet on premises belonging to the two schools of Zacisze. The modest availability of leisure activities, especially in the eastern part of the housing estate, is compensated for by attractive walking routes: a network of safe streets, most of which have sidewalks; Bródnowski Forest adjacent to Zacisze; allotments bordering the housing estate on the eastern side and a few attractive undeveloped land plots located in different parts of Zacisze, which in the future could serve as local squares, playgrounds or outdoor gyms.

The role of places that allow the meeting and maintaining of relationships with other residents of Zacisze is played by local shops, snack bars, beauty salons, hairdressers, as well as places offering artistic activity, including a few private ones and the House of Culture "Zacisze". An important task of integrating the population lies also in two churches. Among the so-called "third places" (Oldenburg 1989, 1997), there are not enough places that offer the sports and recreational activities.

The inhabitants of Zacisze feel the strong need to have a network of local, public spaces and gathering places in the vicinity of their residences. They also want to vitalize social and cultural life, which has been neglected in the past. This is evidenced by the proposals in the participatory budget that will be implemented in 2015 . Among the 14 proposals submitted, four were related to building, upgrading or retrofitting playgrounds, six were ideas for the vitalization of local cultural life, and two related to sports events. Other proposals made, were: opening a library and erecting a monument named "Damned Soldiers" (Żołnierze Wyklęci) - Zacisze, generally, does not have any symbolic places). Finally, a new playground received the most votes.

\section{Results of the survey}

Public spaces and gathering places in Zacisze

Respondents were asked about how often they meet with other residents. The most frequent answers given were at the two extremes: occasionally $(28.2 \%)$ or every day (23.5\%). Daily meetings were more often declared by persons of retirement age and less frequently by people aged $36-60$ years.

If we take into account only those people who have declared that they meet with other residents of Zacisze, it turns out that they do it most often in private homes (59.4\%) (Fig. 1).

Respondents were asked where most of their friends live; more commonly it was pointed out that they came from outside Zacisze (67.1\%).

Residents of the housing estate were asked a few questions about the local public spaces, which had been defined in the questionnaire as: "places publicly available and conducive to establishing relationships. Places such as parks, squares,

${ }^{2}$ In writing about the public spaces of Zacisze, it is worth mentioning that shortly before the local elections, which were scheduled for November 2014, Zacisze was enriched by two new squares with playgrounds, playground equipment and outdoor gym hurriedly installed along Bródnowski Forest, and two mini outdoor gyms in the eastern part of the housing estate. Soon, as part of the revitalization program of the Bródnowski Channel, a new eco-square is expected to be built on one of the stretches of channel. 


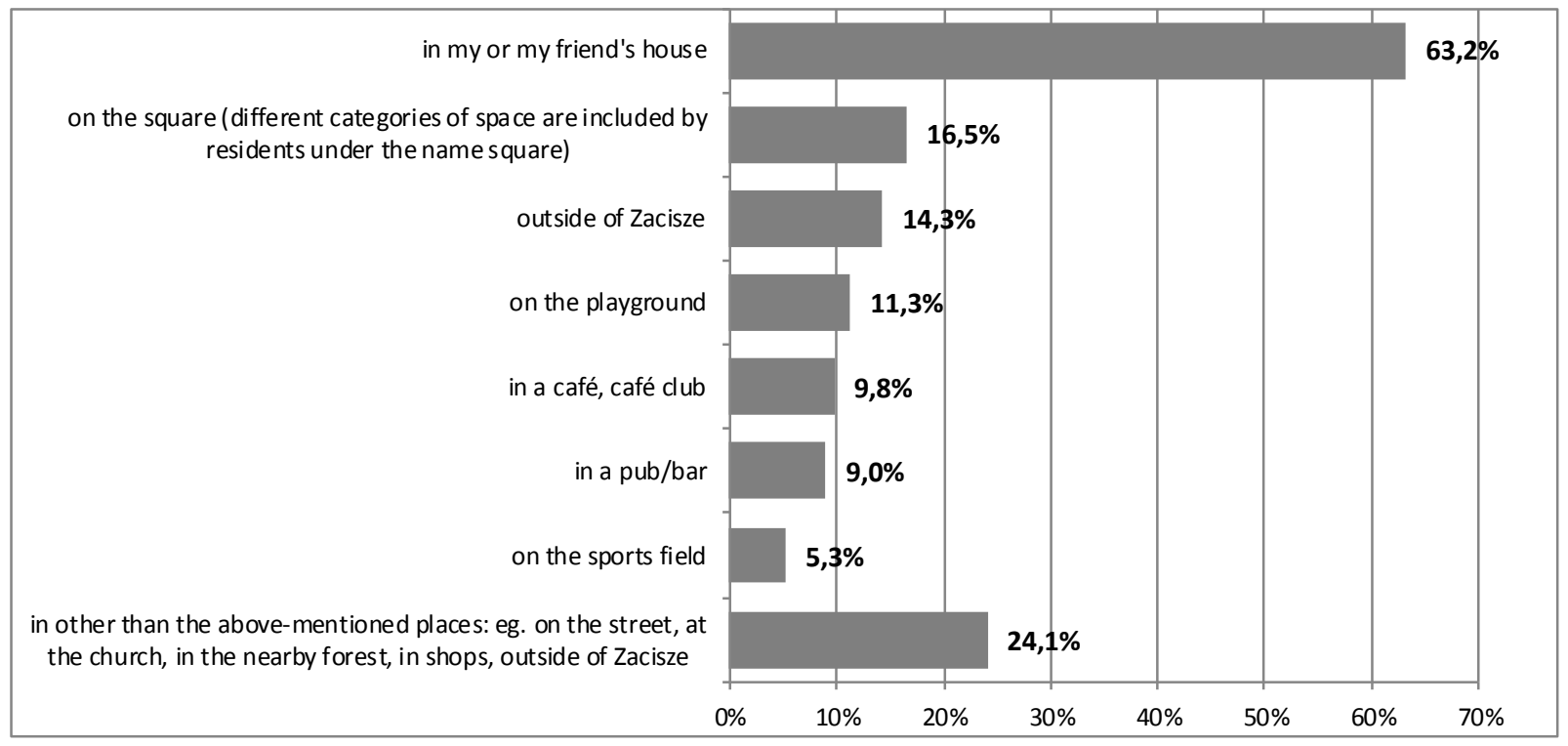

Figure 1. Where do you meet with other residents of Zacisze most often? Source: own elaboration

playgrounds, etc.". It turns out that such places are used "either rarely or frequently" (the average rating on a scale of 1 to 5 , where 1 means "very rarely" and 5 "very frequently", amounted to 2.91). They are more popular among those who have children of up to 13 years old, and less among people who do not have children or do not look after them (t test indicates statistically significant differences in the average values for both groups ${ }^{3}$ ). Local public spaces are more frequently used also by those who for most of the day stay in the housing estate, as opposed to those who spend more time outside Zacisze (also a statistically significant relationship ${ }^{4}$ ).

It was shown that $55 \%$ of respondents (82 people) felt that the public spaces in Zacisze were not conducive to building closer relationships. Of these, up to $75.6 \%$ indicated that the role of those spaces in the integration of population was very low because there were no such places or there were insufficient numbers of them (some spontaneously pointed out that there was a lack of a park, walking and cycling paths, playgrounds, sports fields, or simply benches to sit on). Perhaps this is why up to $78.5 \%$ of respondents said they used also or only, public spaces located outside Zacisze. Residents who use both public spaces in Zacisze and those outside of the housing estate, estimate that they more often choose the latter (up $66.9 \%$ of respondents).

The choice of public open spaces in Zacisze is relatively poor. Residents; however, have at their disposal service and eating places such as local hairdressers, gyms, fitness clubs, bars, and restaurants that could fill this gap. It turns out that the majority of inhabitants $(75.2 \%)$ visit such places, mainly due to the fact that they are close (86.6\% of respondents). Only $15.2 \%$ of respondents admit that they do it for social purposes, treating this type of place as a space of gathering and making contacts.

Attachment to Zacisze in the context of physical and social factor The relationship to the inhabited territory was measured with a subjective assessment of place attachment using a five-point scale, where 1 meant "I don't feel attached at all" and 5 meant "I feel strongly attached". The average rating of attachment to the

${ }^{3} \mathrm{t}_{147}=2.864 ; p<0.01$

${ }^{4} \mathrm{t}_{147}=3.789 ; p<0.01$ housing estate was 3.81 , which meant that residents felt, "rather attached" to it (Fig. 2).

It turns out that the space itself plays an important role in building an attachment to the housing estate. People who often use its public spaces feel more strongly attached to Zacisze than those who spend their free time outside the housing estate (Tab. 3). The observed relationship is statistically significant $\left(\mathrm{t}\right.$-test $\left.{ }^{5}\right)$.

It is also important how frequently one uses local public spaces. Correlation analysis showed a not very strong, but significant, relationship according to which people who often use the public spaces in Zacisze feel more strongly attached to the housing estate (Pearson's correlation coefficient was 0.188 and proved to be significant at the level of 0.05 ).

A similar statistically significant relationship exists between attachment to the housing estate and the use of local services and eating places: people using these types of places feel a stronger attachment to the inhabited territory (t-test $\left.{ }^{6}\right)($ Tab. 4).

The study confirmed that social context played an equally important role in building place attachment. It is reflected in the proportion of the number of friends living in Zacisze to those who live outside it, and in the importance for the respondents in maintaining good relations with their neighbours. The level of importance reflects, on the one hand, the quality of the relationships, and on the other, the need to stay on good terms with co-inhabitants.

Those who have the majority of their friends in Zacisze feel more strongly attached to the housing estate than those who make friends from outside it. (Tab. 5). The observed relationship is statistically significant (t-test $\left.{ }^{7}\right)$, and the difference in average values is higher than for the groups separated due to the location of the public spaces (within Zacisze or outside it) (see Tab. 3). This; therefore, leads to the conclusion that place attachment is to a greater extent a product of the relationships with other residents, than a result of the use of local public spaces. Proving such regularity - however, requires additional research.

\footnotetext{
${ }^{5} t_{116}=2.939 ; p<0.01$

${ }^{6} \mathrm{t}_{147}=3.354 ; p<0.01$

${ }^{7} \mathrm{t}_{147}=4.420 ; p<0.01$
} 
MISCELLANEA GEOGRAPHICA - REGIONAL STUDIES ON DEVELOPMENT

Vol. $19 \cdot$ No. 3 • 2015 • pp. 36-42 • ISSN: 2084-6118 • DOI: 10.1515/mgrsd-2015-0013

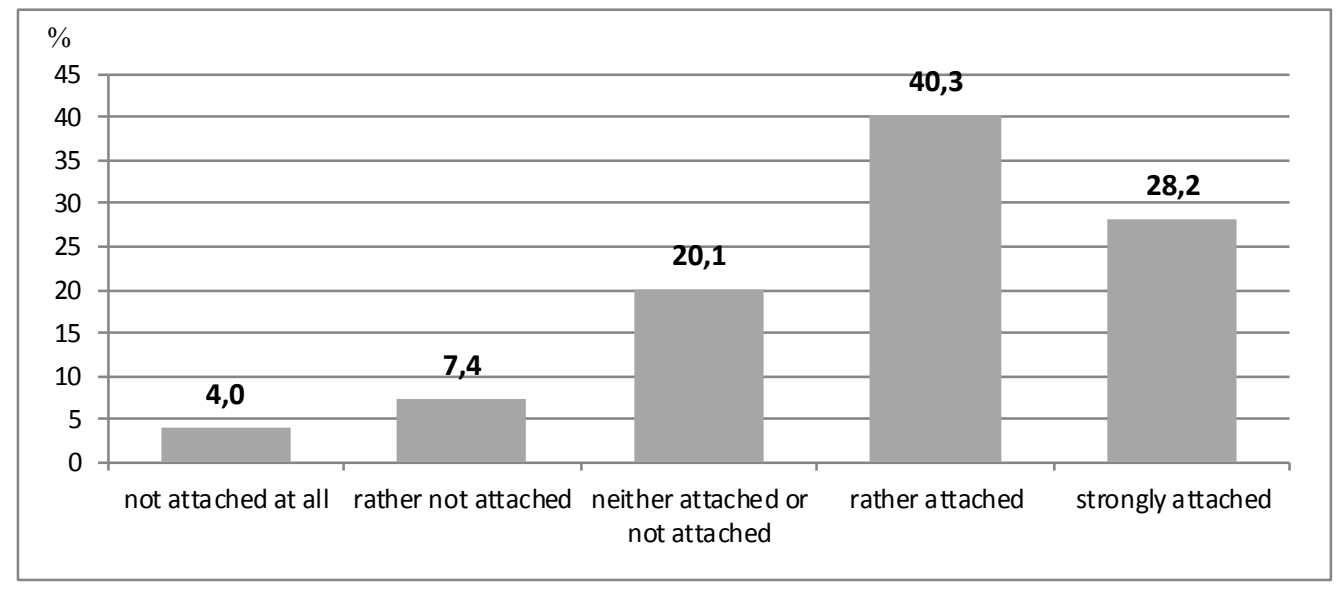

Figure 2. How much do you feel attached to Zacisze?

Source: own elaboration

Table 3. Attachment to Zacisze due to the use of its public spaces

\begin{tabular}{|c|c|c|c|}
\hline $\begin{array}{c}\text { Which public spaces do } \\
\text { you use more often? }\end{array}$ & $\mathbf{N}$ & Average & $\begin{array}{c}\text { Standard } \\
\text { deviation }\end{array}$ \\
\hline public spaces in Zacisze & 39 & $\mathbf{4 . 0 8}$ & 0.807 \\
\hline $\begin{array}{c}\text { public spaces outside of } \\
\text { Zacisze }\end{array}$ & 79 & $\mathbf{3 . 4 8}$ & 1.131 \\
\hline
\end{tabular}

Source: own elaboration

Table 4. Attachment to Zacisze due to the use of local service and eating places

\begin{tabular}{|c|c|c|c|}
\hline $\begin{array}{c}\text { Do you use local services } \\
\text { and eating places such as: } \\
\text { pizza place, coffee shop, a } \\
\text { local hairdresser, } \\
\text { gym/fitness? }\end{array}$ & $\mathbf{N}$ & Average & $\begin{array}{c}\text { Standard } \\
\text { deviation }\end{array}$ \\
\hline YES & 112 & $\mathbf{3 . 9 7}$ & 0.925 \\
NO & 37 & $\mathbf{3 . 3 2}$ & 1.270 \\
\hline
\end{tabular}

Source: own elaboration

Table 5. Attachment to Zacisze due to the place where most of one's friends live

\begin{tabular}{|c|c|c|c|}
\hline $\begin{array}{c}\text { Where do most of your } \\
\text { friends live? }\end{array}$ & $\mathbf{N}$ & Average & $\begin{array}{c}\text { Standard } \\
\text { deviation }\end{array}$ \\
\hline in Zacisze & 49 & $\mathbf{4 . 3 3}$ & 0.826 \\
\hline outside of Zacisze & 100 & $\mathbf{3 . 5 6}$ & 1.067 \\
\hline
\end{tabular}

Source: own elaboration

The above mentioned relationship is confirmed by the statistically significant correlation between the attachment to Zacisze, and the assessment of the importance for the respondents in maintaining good relations with their neighbours. Pearson's correlation coefficient was $-0.292^{8}$, it turned out to be

${ }^{8} \mathrm{~A}$ negative value of the coefficient is due to the fact that in the case of assessing the importance of maintaining good relations with the neighbors, a higher value means "less important", and in the case of assessing the attachment to Zacisze, a higher value represents stronger attachment. significant at the level of 0.01 and was higher than in the case of the relationship between the attachment to the housing estate and the frequency of using local public spaces. It is worth noting that neighbourhood relations were rated by the respondents as "rather good" (the average rating on a scale of 1 to 5 was 1.97), and the importance of maintaining good relations with the neighbours as "rather important" (the same average value on the same rating scale).

\section{Discussion}

The research on Zacisze, one of Warsaw's detached housing estates, falls into a fairly wide stream of research on place attachment. It is a detailed study taking into account the context that consists of the size and the characteristics of a specific fragment of urban space.

The study of the Zacisze housing estate contributes to the relatively few studies on the determinants of attachment to a part of the city that is larger than a neighbourhood, which, despite its seeming attractiveness, lacks the factors that effectively reinforce a relationships of familiarity and intimacy with the territory.

The above statement is reflected in the research on the quality of life in Warsaw districts, where respondents were asked a similar question about their attachment to the district and to the vicinity of their residence ${ }^{9}$. It turns out that the inhabitants of Targówek, to which Zacisze belongs, shows medium district attachment, where $68 \%$ declared an emotional tie with Targówek, ranking it at seventh place among all eighteen districts of Warsaw. The result for Zacisze does not diverge from the percentage of residents in Targówek attached to the district; the attachment to the housing estate is declared by $68.5 \%$ of its adult population.

If you reduce the spatial scale and take into account the attachment to the area within the vicinity of the residence, it turns out that Zacisze definitely has a worse result than for the whole of Targówek. Emotional ties with the vicinity of residence were declared by $74 \%$ of the population of Targówek (Fig. 3), but only $68.5 \%$ of those who live in Zacisze.

The study of the relationship between the use of local public spaces and the attachment to Zacisze, as well as similar studies done by other authors, does not resolve the problem of the direction of the relationship. Using attractive public spaces strengthens the attachment to the housing estate/district, but on

${ }^{9}$ The research was commissioned by the Office of the City of Warsaw and carried out from October to December 2013 on a random, representative sample of the residents of Warsaw districts aged 15 years and older. There was a total number of 7,200 interviews completed (400 in each of the districts). They are available from: <http:// www.um.warszawa.pl/o-warszawie/warszawa-w-liczbach/jako-ycia> 


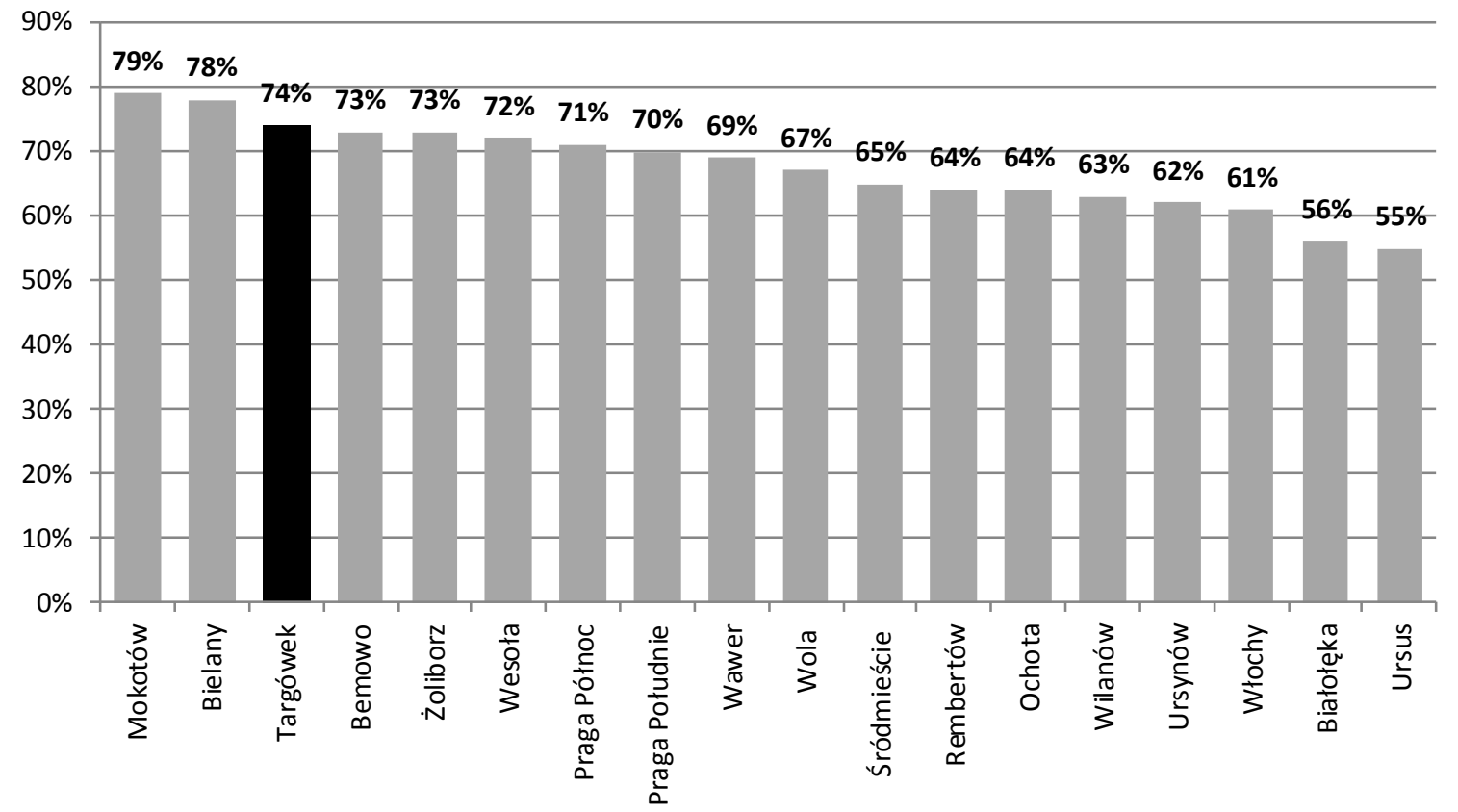

Figure 3. Attachment to the vicinity of residence

Source: own elaboration on the basis of the study "The quality of life in the districts of Warsaw", produced for the Office of the City of Warsaw (Jakość życia... 2013)

the other hand, people that are strongly attached to the area use local gathering and leisure places more often than those whose relations to the territory are not so strong.

Given the current state of knowledge, the study still does not determine which of the factors, physical or social, exerts a greater influence on place attachment, though a stronger correlation was observed in the case of the latter. Thus, it confirms the research done by Lewicka (2010), who claims that the social factor is a more important predictor of the attachment to larger fragments of the urban fabric, such as neighbourhoods or districts.

\section{Conclusions}

The results of the research on Zacisze prove the role of the two remaining inter-dependant factors of place attachment, one of which is the use of local public spaces, and the second being the density of human interactions. Although the study does not indicate it directly, the lack of opportunities for using local gathering and leisure places is an essential factor in the belief that this effectively reduces the attachment to the inhabited area (in this case a housing estate). An equally important factor in building relations to territory is social context in its wider sense. Strong ties with other residents, a wide circle of friends and a sense of rootedness translate into stronger attachment to the territory. The desirable solution; therefore, would be to create a network of public spaces that would allow not only the spending of spare time outside the house, but also allow interaction with society. Today the pro-social nature of public space, positive relations with neighbours, and in general the opportunity to participate in public life, are among the most important factors implying a positive relationship to the territory. The homogeneity and small scale of the space (typical for the neighbourhood), as well as the physical attractiveness of the housing estate due to of its suburban nature, may not be sufficient in the case of building a strong attachment to the territory.

The author suggests a repetition of the research on Zacisze as it is expected that the public spaces that have appeared there after the end of the survey, or will soon appear, should strengthen the average attachment to the housing estate (assuming that these places will be used by people hitherto deprived of such a possibility). The repeated research should provide additional evidence that the amount of use and the access to gathering places are important factors in shaping the relationship to territory. It is, at the same time, an incentive for local authorities to take care of the mature utility program for residents.

\section{References}

Bonaiuto, M, Fornara, F \& Bonnes, M 2003, 'Indexes of perceived residential environment quality and neighborhood attachment in urban environments: a confirmation study on the city of Rome', Landscape and Urban Planning, vol. 65, pp. 41-52.

Burdzik, T 2012, 'Przestrzeń jako składnik tożsamości w świecie globalizacji', Kultura - Historia - Globalizacja, no. 11, Available from: <http://www.khg.uni.wroc. $\mathrm{pl} /$ ?type=archiwum\&nr=11>. [8 December 2014].
Carr, S \& Francis, M \& Rivlin, LG \& Stone AM 1992, Public Space, Cambridge University Press, Cambridge.

Droseltis, O \& Vignoles,VL 2010, 'Towards an integrative model of place identification: Dimensionality and predictors of intrapersonal-level place preferences', Journal of Environmental Psychology, vol. 30, issue 1, pp. 23-34.

Fornara, F, Bonaiuto, M \& Bonnes, M 2009, 'Cross-validation of Abbreviated Perceived Residential Environment Quality 
(PREQ) and Neighborhood Attachment (NA) indicators', Environment and Behavior, vol. 42, pp.171-196.

Gehl, J 2010, Cities for People, Island Press.

Górka, A 2013, 'Małe miasta w dużych, duże miasta w małych - wspólnoty lokalne czy alienacja w przestrzeni publicznej', Acta Universitatis Lodziensis, Folia Geographica SocioOeconomica, vol. 15, pp. 293-304.

Gustafson, P 2006, 'Place attachment and mobility' in Mulitiple dwelling and tourism: Negotiating place, home and identity, eds N McIntyre \& KE McHugh , CAB International, pp. 1731.

Hester, RT 1984, Planning Neighborhood Space with People, Van Nostrand Reinhold, New York.

Hidalgo, MC \& Hernández, B 2001, 'Place Attachment: Conceptual and Empirical Questions', Journal of Environmental Psychology, vol. 21, pp. 273-281.

Jacobs, A 1999, Great streets, MIT Press, Cambridge.

Jacobs, J 1961, The Death and Life of Great American Cities, Random House, New York.

Jakość życia w dzielnicach. Badanie jakości życia mieszkańców warszawskich dzielnic zrealizowano w 2013 r. wśród mieszkańców 18 dzielnic Warszawy 2013, Available from: http://www.um.warszawa.pl/o-warszawie/warszawa-wliczbach/jako-ycia [8 December 2014].

Janz, B 2005, 'Walls and borders: The range of places', City \& Community, vol. 4, pp. 87-94.

Knez, I 2005, 'Attachment and identity as related to a place and its perceived climate', Journal of Environmental Psychology, vol. 25, pp. 207-218.

Kruger, LE \& Jakes, PJ 2003, 'The importance of place: Advances in science and application', Forest Science, vol. 49, pp. 819821.

Lewicka, M 2004, 'Identyfikacja z miejscem zamieszkania mieszkańców Warszawy: determinanty i konsekwencje' in Społeczna mapa Warszawy, eds J Grzelak \& T Zarycki, Wydawnictwo Naukowe Scholar, Warszawa, pp. 273-315.

Lewicka, M 2006, 'Dwa miasta - dwa mikrokosmosy. Wrocław i Lwów w pamięci swoich mieszkańców' in My Wrocławianie. Społeczna przestrzeń miasta, eds P Żuk \& J Pluta, Wydawnictwo Dolnośląskie, Wrocław, s. 99-133.

Lewicka, M 2008, 'Place attachment, place identity, and place memory: Restoring the forgotten city past', Journal of Environmental Psychology, vol. 28, 209-231.

Lewicka, M 2010, 'What makes neighborhood different from home and city? Effects of place scale on place attachment', Journal of Environmental Psychology, vol. 30, pp. 35-51.

Lewicka, M 2011, 'Place attachment: How far we come in the last 40 years?', Journal of Environmental Psychology, vol. 31, pp. 207-230.

Lewicka, M, Bilewicz, M, Wieczorek, A, Kuzko, K, Foland, A \& Wójcik, A 2007, Muranów i Muzeum Historii Żydów Polskich: tożsamość mieszkańców, pamięć miejsca, postrzeganie dzielnicy $i$ jej żydowskiej historii. Raport z badań, Centrum Badań nad Uprzedzeniami i Pracownia Badań Środowiskowych Wydziału Psychologii Uniwersytetu Warszawskiego, Warszawa
Livingston, M, Bailey, N \& Kearns, A 2008, People's attachment to place - The influence of neighbourhood deprivation, Glasgow University, Available from: <http://www.jrf.org.uk/ system/files/2200-neighbourhoods-attachment-deprivation. pdf>. [8 December 2014].

Michalska, A 2003, 'Indywidualny i kolektywny wymiar identyfikacji przestrzennej', Studia Regionalne i Lokalne, vol. 4(14), pp. 77-90.

Nasar, JL 1998, The evaluative image of the city, Sage, Thousand Oaks

Oldenburg, R 1989, The Great Good Place: Cafes, Coffee Shops, Bookstores, Bars, Hair Salons, and Other Hangouts at the Heart of a Community, MARLOWE \& COMPANY, New York.

Oldenburg, R 1997, 'Our vanishing third places', Planning Commissioners Journal, no. 25, pp. 6-10.

Pawłowska, K 1996, Idea swojskości w urbanistyce i architekturze miejskiej, Politechnika Krakowska, Seria Architektura, Monografia 203, Kraków.

Rogers, GO \& Sukolratanametee, S 2009, 'Neighborhood Design and Sense of Community: Comparing Suburban Neighborhoods in Houstan Texas', Landscape and Urban Planning, vol. 92, pp. 325-334.

Rychlewska, P 2010, 'Psychospołeczne więzi z miejscem zamieszkania mieszkańców warszawskiego Młynowa i podwarszawskiego Pomiechówka', Kultura i Historia, nr 17/2010, Available from: <http://www.kulturaihistoria.umcs. lublin.pl/archives/1834>. [8 December 2014].

Rykiel, Z 1999, 'Przemiany struktury społeczno-przestrzennej miasta polskiego a świadomość terytorialna jego mieszkańców', Prace Geograficzne, no. 170, PAN IGiPZ, Wydawnictwo Continuo, Warszawa.

Stolle, D \& Soroka, S \& Johnston, R 2008, 'When Does Diversity Erode Trust? Neighborhood Diversity, Interpersonal Trust and the Mediating Effect of Social Interactions', Political Studies, 56, pp. 57-75.

Talen, E 1999, 'Sense of Community and Neighborhood Form: An Assessment of the Social Doctrine of New Urbanism', Urban Studies, vol. 36, no. 8, pp. 1361-1379.

Tuan, YF 1975, 'Place: An experiential perspective', Geographical Review, vol. 6, pp. 191-210.

Tuan, YF 1977, Space and place: The perspective of experience, The University of Minnesota Press, Minnesota.

Wallis, A 1979, Informacja i gwar: o miejskim centrum, PIW, Warszawa. 